ISSN 0258-7122 (Print), 2408-8293 (Online)

Bangladesh J. Agril. Res. 42(3): 447-456, September 2017

\title{
EFFECT OF COMPOST TEA, STREPTOMYCIN AND CUPRAVIT IN CONTROLLING BACTERIAL LEAF BLIGHT OF RICE
}

\author{
A. SHISHIR ${ }^{1}$, M. M. KAMAL ${ }^{2}$, M. A. R. KHOKON ${ }^{3}$ \\ M. R. ISLAM ${ }^{4}$ AND S. DAS ${ }^{5}$
}

\begin{abstract}
Compost tea, streptomycin and cupravit were evaluated against the Bacterial Leaf Blight diseases of rice cv. BR11 in two management approaches (preventive and curative) under field condition. The selected cultivar BR11 was cultivated in the field laboratory of the Department of Plant Pathology, Bangladesh Agricultural University, Mymensingh, Bangladesh during the period from July to December 2012. The field experiment was carried out with seven treatments in Randomized Complete Block Design (RCBD) and each was replicated thrice. The treatments were $\mathrm{T}_{0}=$ Control, $\mathrm{T}_{1}=$ Compost tea as foliar spray 2 times (preventive) @ 1:5 w/v, $\mathrm{T}_{2}=$ Compost tea as foliar spray 2 times (Curative) @ 1:5 w/v, $\mathrm{T}_{3}=$ Streptomycin as foliar spray 2 times (preventive) @ $1 \mathrm{gm} / 10 \mathrm{~L}, \mathrm{~T}_{4}=$ Streptomycin as foliar spray 2 times (Curative) @ 1gm/10 L, $\mathrm{T}_{5}=$ Cupravit as foliar spray 2 times (preventive) @ $0.2 \%, \mathrm{~T}_{6}=$ Cupravit as foliar spray 2 times (Curative) @ 0.2\%. Cupravit as foliar spray 2 times (Curative)@ $0.2 \%$ showed marked effect in reducing Bacterial Leaf Blight diseases of BR11 rice as well as enhancing yield and yield contributing characters. The effect of compost tea also produced similar effects on disease and yield of rice over control. Among the application options of different treatment, curative application provided better results than preventive under field condition.
\end{abstract}

Keywords: Compost tea, streptomycin, cupravit, bacterial leaf blight, rice

\section{Introduction}

Rice (Oryza sativa L.) is the most important cereal crop in Bangladesh covering 11533198.38 hectares of land (BBS, 2012). The average world yield of rice is 4.48 metric tons/hectare, but the average yield in Bangladesh is measurably poor, only 2.94 metric tons/hectare (FAO, 2013; BBS, 2012). This indicates that average per hectare yield of rice in Bangladesh is extremely low compared to other rice growing countries of the world.

Among the many reasons of low yield of rice in Bangladesh, diseases and insect pests play a major role, sometimes leading to disastrous consequences (Fakir, 1982). Out of 32 diseases of rice, ten are considered major, among them bacterial

\footnotetext{
${ }^{1}$ Department of Plant Pathology, Bangladesh Agricultural University (BAU), Mymensingh-2202, ${ }^{2 \& 5}$ Assistant Professor, Agrotechnology Discipline, Khulna University, Khulna-9208, ${ }^{3 \& 4}$ Professor, Department of Plant Pathology, BAU, Mymensingh-2202, Bangladesh
} 
leaf blight (BLB) has been considered as most important one because of their widespread outbreak and significant yield loss potential (Khan et al., 2010).

Bacterial leaf blight (BLB) caused by Xanthomonas oryzae pv. oryzae (Xoo) is the most devastating bacterial disease of rice worldwide (Thein and Prathuangwong, 2010). The yield loss caused by BLB in Bangladesh has been estimated as $5-29 \%$ depending on the crop stage, variety and season (BRRI, 2004). This disease is being controlled especially by spraying chemical or bactericides in the field as well as by treating seeds with the seed treating chemicals and using disease resistant cultivars. Especially in Bangladesh, there is no recommended bactericides that can control BLB effectively under field condition (Khan et al., 2010).

Farmers generally use chemicals for the control of this disease but indiscriminate use of chemicals resulted environmental pollution and health hazards. As an alternate means of avoiding these problems, biological agents are being used for combating the diseases with the aim of increasing crop production. The biological control of pathogen offers environmentally safe, durable and cost effective alternatives to chemical compounds (Perveen et al., 1994). Living microorganisms such as bacteria, viruses or fungi are employed in biological control either as antagonists, parasites or competitor (Kwok et al., 1987).

Compost tea has been defined simply as liquid extract from compost material that may contain organic and inorganic soluble nutrients, and a large number of organisms including bacteria, fungi, protozoa and nematodes (Rou, 2003). It is emerging as a crop protection tool and has been using for organic agriculture for a number of reason viz. it contains microorganisms which can reduce the incidence of foliar and/or soil-borne diseases, a readily available nutrients which rapidly benefit plant growth through direct contribution to plant nutrition and is easily integrated into existing plant fertility and disease control programs due to its easy application via existing irrigation or spray equipment, or as a soil drench. Assuming all the above mentioned facts, the present study was undertaken to find out the effect of compost tea on the incidence and severity of Bacterial Leaf Blight disease and impact on yield of BR11 rice.

\section{Materials and Method}

\section{Experimental Site and Seed Sowing}

An experiment was conducted at the Field Laboratory of Department of Plant Pathology, Bangladesh Agricultural University, Mymensingh during the period from July 2012 to December 2012. A high yielding cultivar BR11 (Mukta) was selected for this study. Seeds of BR11 (Mukta) were collected from seed store of Bangladesh Agricultural Development Corporation (BADC), seed building, Monakhola, Mymensingh. 
A small piece of medium low land of the experimental farm of the Department of Plant pathology, Bangladesh Agricultural University, Mymensingh was puddled with the power tiller. Clean and mature seeds were soaked in tap water for 24 hours and incubated 48 hours for germination before sowing in the seed bed. The germinated seeds were sown in the seed bed on 5 July 2012.

\section{Field Experiment Setting}

The experiment was laid out in a Randomized Complete Block Design (RCBD) with 3 replications maintaining distance between the blocks and the plots as 50 $\mathrm{cm}$ and $25 \mathrm{~cm}$, respectively. A total of 7 treatments were used henceforth designated as $\mathrm{T}_{0}$ (Control), $\mathrm{T}_{1}$ (Compost tea as foliar spray 2 times (preventive) @ 1:5 w/v, $\mathrm{T}_{2}$ (Compost tea as foliar spray 2 times (Curative) @ 1:5 w/v, $\mathrm{T}_{3}$ (Streptomycin as foliar spray 2 times (preventive) @ 1gm/10 L, T4 (Streptomycin as foliar spray 2 times (Curative) @ $1 \mathrm{gm} / 10 \mathrm{~L}, \mathrm{~T}_{5}$ (Cupravit as foliar spray 2 times (preventive) @ 0.2\%) and $\mathrm{T}_{6}$ (Cupravit as foliar spray 2 times (Curative) @ $0.2 \%$.

The main land was prepared by power tiller on $8^{\text {th }}$ August 2012. Later on the individual plots were cleaned from weeds and stubbles. Organic amendments and Chemical fertilizers were applied in the field as recommended by Bangladesh Agricultural Research Council (Anonymous, 2005). The border of each unit plot was raised to prevent the fertilizer and nutrients movement from one plot to others.

\section{Transplanting of Seedlings of BR 11 (Mukta) and Preparation of Compost Tea}

After preparing the land, 32 days of old seedlings of BR 11 (Mukta) were uprooted carefully to avoid root injury. The seedlings were transplanted putting three seedlings/hill where plant to plant and row to row spacing were $15 \mathrm{~cm}$ and $20 \mathrm{~cm}$, respectively. Weeding and other cultural practice was performed in time.

Compost tea was obtained by mixing compost with tap water at a ratio of 1:5(w/v) followed by fermentation for one week. Then it was stirred once every day and allowed to ferment in the Net house of Seed Pathology Centre, BAU, Mymensingh at $25^{\circ} \mathrm{C}$. After 7 days, the solution was filtered through cheese cloth to obtain the compost tea.

\section{Inoculum preparation and Inoculation of test entries}

$\mathrm{BXO}$, a virulent and reference isolate of major races of Xanthomonas oryzae pv. oryzae (Khan et al., 2010) was obtained from the Plant pathology Division, BRRI for inoculation. The isolate was cultured on Peptone Sucrose Agar (PSA) slants for 72 hours at $30^{\circ} \mathrm{C}$. Inoculum was prepared by mixing the cultured bacteria with $10 \mathrm{ml}$ sterile distilled water in a slant. Before inoculation the concentration of the bacterial suspension was adjusted to $10^{8}$ to $10^{10} \mathrm{CFU} / \mathrm{ml}$ 
using sterile water. The leaf clipping inoculation method was adopted in this experiment. The scissors were dipped into bacterial suspension, and then the tip of fully expanded leaves were clipped as described by Kauffman et al. (1973).

\section{Identification of the symptom of Bacterial Leaf Blight of rice}

The rice plants were examined periodically and bacterial leaf blight infection was identified on the basis of symptoms developed on the plants as described by Tabei and Mukoo (1960). At first a tiny water soaked lesion appeared from the leaf margin, then turned yellow while enlarging both the length and width to develop an elongated irregular lesion. The border of the lesion adjoining the healthy part showed a wavy margin lesions might start on one or both margins of the leaf.

\section{Assessment of incidence and severity of disease}

Data on lesion length, relative lesion length and leaf area damaged were recorded at 7 and 14 days after inoculation (DAI). Lesion length was measured by measuring scale. Total number of inoculated leaves per hill and number of infected leaves per hill was recorded. Both at natural and inoculated conditions, 5 hills and 5 leaves were randomly selected from each plot to collect data on total number of leaves per hill, number of infected leaves per hill, total leaf length $(\mathrm{cm})$ and leaf lesion length $(\mathrm{cm})$.

The disease incidence was calculated by the following formula:

Disease incidence (I) $\%=\frac{\text { Number of infectedleaves }}{\text { Totalnumber of leaves }} \times 100$

Percent leaf area diseased/severity was assessed by the following formula:

Severity $\%=\frac{\text { Leaf area diseased }}{\text { Totalleaf area }} \times 100$

\section{Harvesting and recording of data}

Randomly selected 15 tillers from each plot (inoculated and non-inoculated) were used for recording the data on Plant height $(\mathrm{cm})$, No of tiller/plant, Panicle length $(\mathrm{cm})$, Total number of grains/panicle, Chaffy grain number/ panicle and Grain weight $(\mathrm{gm}) /$ plot.

\section{Analysis of data}

The collected data were analyzed using the Analysis of variance (ANOVA) technique, and the mean differences were adjudged by Duncan's Multiple Range Test (Gomez and Gomez, 1984) using the statistical computer package. 


\section{Results and Discussion}

Effect of compost tea, streptomycin and cupravit on against BLB of rice in the field

Effect of different treatments on incidence of BLB at 7 DAI was variable and ranged from $52.82 \%$ to $86.26 \%$ (Fig. 1). Highest BLB incidence $(86.26 \%$ ) was observed in $\mathrm{T}_{0}$ (control) which was statistically similar to $\mathrm{T}_{3}$ (streptomycin preventive), the lowest disease incidence (52.82\%) was in $\mathrm{T}_{6}$ (cupravit curative).

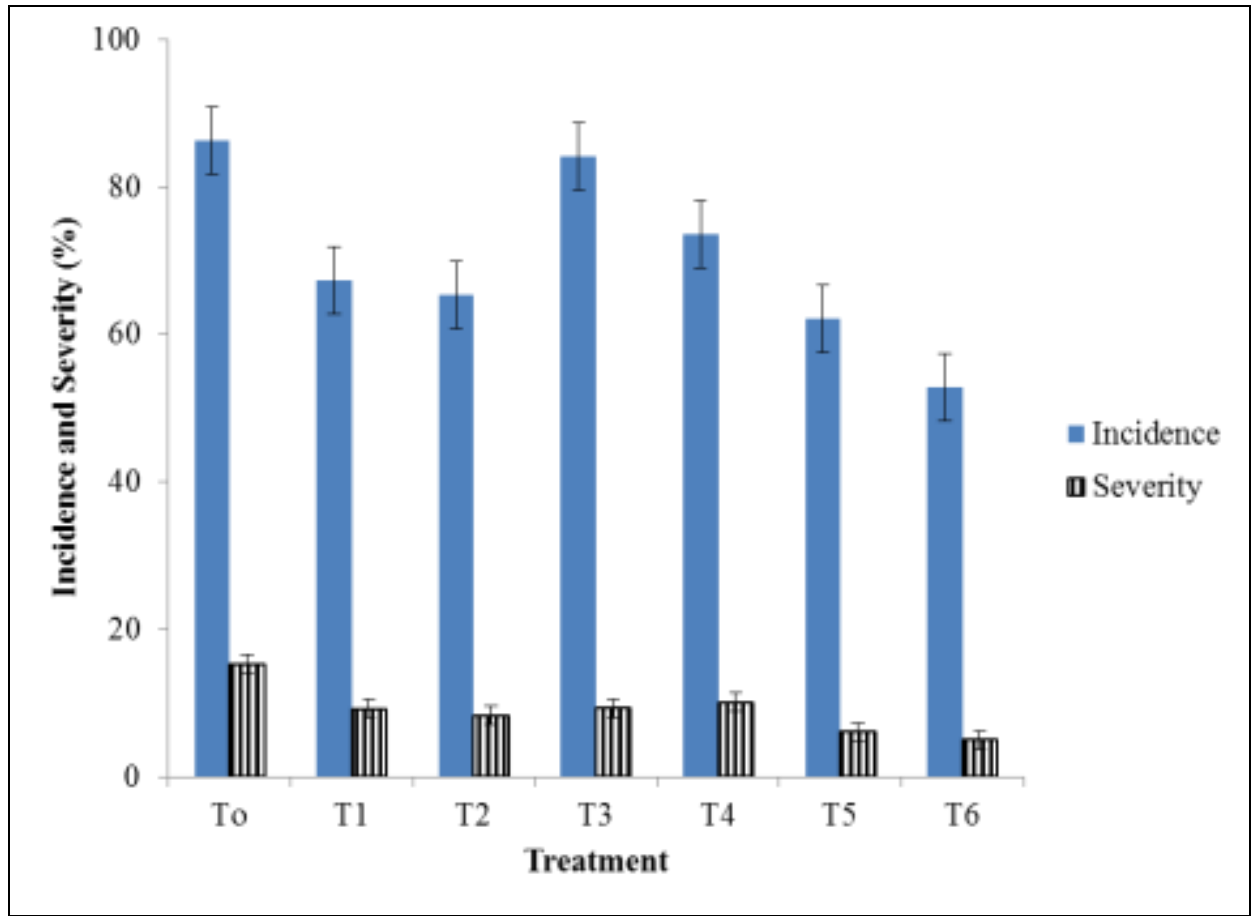

Fig.1. Effects of different treatments on the incidence and severity of BLB of cv.BR11, at 7 DAI.

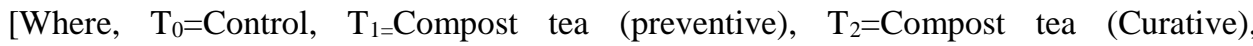
$\mathrm{T}_{3=}$ Streptomycin (preventive), $\mathrm{T}_{4=}$ Streptomycin (Curative), $\mathrm{T}_{5}=$ Cupravit (preventive) and $\mathrm{T}_{6=}=$ Cupravit (Curative)]

Besides, disease severity at 7 DAI ranged from $5.01 \%$ to $15.33 \%$ (Fig.1). Highest disease severity $(15.33 \%)$ was observed in $\mathrm{T}_{0}$ (control) which is statistically similar to $\mathrm{T}_{4}$ (streptomycin curative) whereas the lowest disease severity $(5.01 \%)$ was found in $\mathrm{T}_{6}$ (cupravit curative) which is statistically similar to $\mathrm{T}_{5}$ (cupravit preventive).

Incidence of BLB varied from $83.09 \%$ to $94.04 \%$ at 14 DAI in field (Fig.2). Highest BLB incidence (94.04\%) was observed in $\mathrm{T}_{0}$ (Control) which was statistically similar to $\mathrm{T}_{4}$ (streptomycin curative), $\mathrm{T}_{3}$ (streptomycin preventive), 
while the lowest BLB incidence $(83.09 \%)$ was observed in $\mathrm{T}_{6}$ (cupravit curative), which was statistically similar to $\mathrm{T}_{5}$ (cupravit preventive) and $\mathrm{T}_{2}$ (compost tea curative).

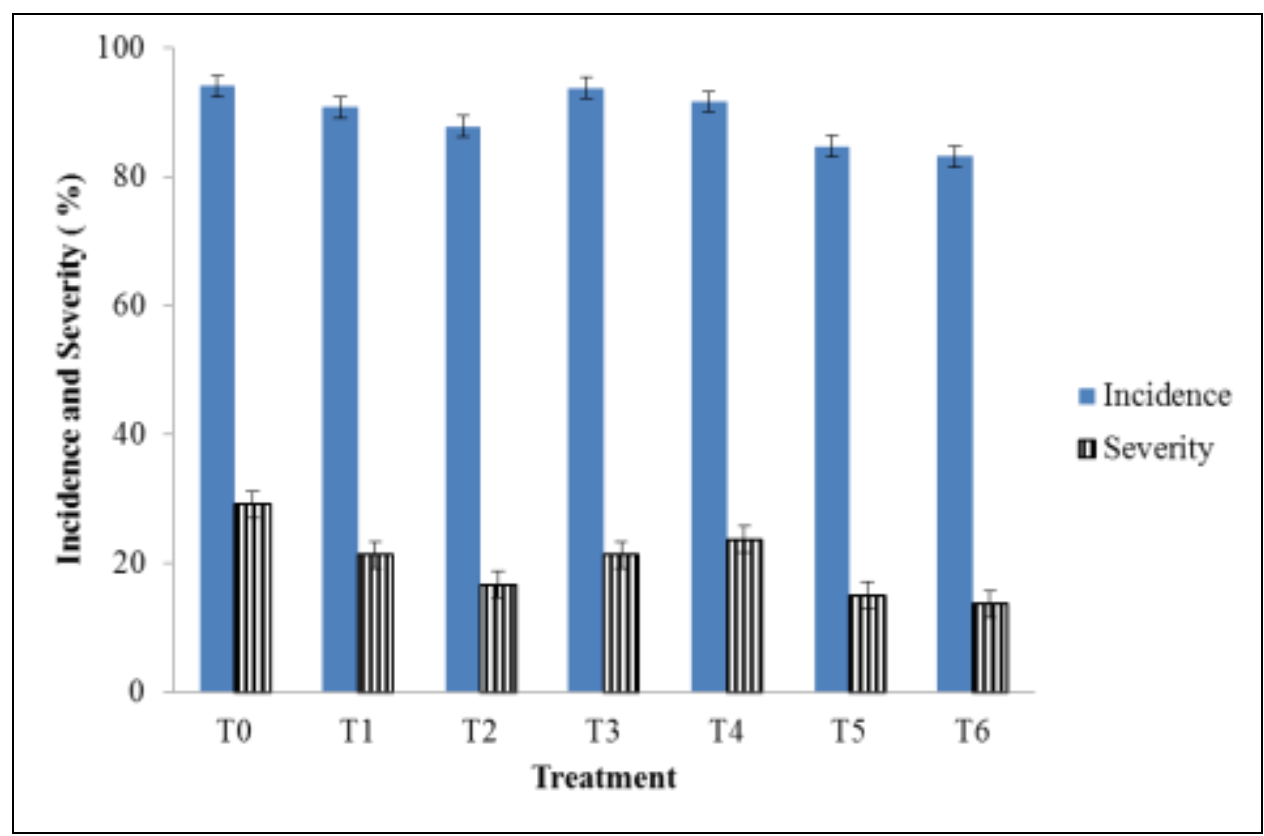

Fig.2. Effects of different treatments on the incidence and severity of BLB of rice cv.BR11 at 14 DAI.

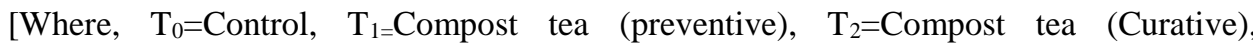
$\mathrm{T}_{3=}$ Streptomycin (preventive), $\mathrm{T}_{4=}$ Streptomycin (Curative), $\mathrm{T}_{5}=$ Cupravit (preventive) and $\mathrm{T}_{6}=$ Cupravit (Curative)]

The disease severity of rice under different treatments at 14 DAI was also varied (Fig. 2) and the highest severity (29.21\%) was found in control treatment $\left(\mathrm{T}_{0}\right)$, while the lowest severity (13.69\%) was recorded in $\mathrm{T}_{6}$ (cupravit curative), which was statistically similar to $T_{2}$ (compost tea curative) and to $T_{5}$ (cupravit preventive).

There was a significant variation among the treatments regarding the incidence of bacterial leaf blight of rice that varied from $52 \%$ to $94 \%$. BLB incidence was significantly lower in compost tea treatment which was statistically similar to cupravit whereas application of streptomycin did not show any significant effect on BLB of rice. Similarly cupravit showed marked effect on severity of BLB which is statistically similar to compost tea application. This result was fully in agreement with the findings (Kumar et al., 2009) who found that among the chemicals copper oxychloride $(0.25 \%)$ was most effective over other chemicals. Likewise, compost tea foliar sprays also gave good response to BLB management as compared to Streptomycin and control treatments. These results were fully agreement with the findings of Wickramaarachchi et al. (2003). Ryan 
et al. (2005) also explored the use of aerated water extracts or teas from compost to control foliar diseases. In this experiment streptomycin (antibiotics) had little effect on BLB of rice as compared to cupravit and compost tea. Similar findings were reported by Padmanabhan and Jain (1966).

Effect of Compost tea, streptomycin and cupravit on yield and yield components of rice cv.BR11

Table 1. Effect of different treatment on the growth and yield of rice CV. BR11

\begin{tabular}{c|l|l|l|l|l|l}
\hline Treatments & $\begin{array}{c}\text { Plant } \\
\text { height } \\
(\mathrm{cm})\end{array}$ & $\begin{array}{c}\text { No. of } \\
\text { tiller/plant }\end{array}$ & $\begin{array}{c}\text { Panicle } \\
\text { length } \\
(\mathrm{cm})\end{array}$ & $\begin{array}{c}\text { Total grain } \\
\text { number/ } \\
\text { panicle }\end{array}$ & $\begin{array}{c}\text { Chaffy } \\
\text { grain } \\
\text { number/ } \\
\text { panicle }\end{array}$ & $\begin{array}{c}\text { Grain } \\
\text { weight } \\
(\mathrm{g}) / \mathrm{plot}\end{array}$ \\
\hline $\mathrm{T}_{\mathrm{o}}$ & $104.80 \mathrm{ab}$ & $14.27 \mathrm{ab}$ & $22.39 \mathrm{~b}$ & $132.69 \mathrm{~d}$ & $45.78 \mathrm{~b}$ & $726.67 \mathrm{e}$ \\
$\mathrm{T}_{1}$ & $100.60 \mathrm{bc}$ & $16.00 \mathrm{ab}$ & $24.50 \mathrm{~b}$ & $144.78 \mathrm{c}$ & $42.22 \mathrm{bc}$ & $793.33 \mathrm{c}$ \\
$\mathrm{T}_{2}$ & $107.10 \mathrm{a}$ & $16.27 \mathrm{ab}$ & $22.29 \mathrm{~b}$ & $159.22 \mathrm{~b}$ & $45.22 \mathrm{bc}$ & $826.67 \mathrm{~b}$ \\
$\mathrm{~T}_{3}$ & $98.17 \mathrm{c}$ & $13.93 \mathrm{~b}$ & $22.16 \mathrm{~b}$ & $147.01 \mathrm{c}$ & $51.33 \mathrm{a}$ & $760.00 \mathrm{~d}$ \\
$\mathrm{~T}_{4}$ & $95.97 \mathrm{~d}$ & $14.33 \mathrm{ab}$ & $23.44 \mathrm{~b}$ & $146.89 \mathrm{c}$ & $43.89 \mathrm{bc}$ & $726.67 \mathrm{e}$ \\
$\mathrm{T}_{5}$ & $98.78 \mathrm{bc}$ & $17.20 \mathrm{a}$ & $23.58 \mathrm{~b}$ & $158.55 \mathrm{~b}$ & $41.44 \mathrm{bc}$ & $766.67 \mathrm{~d}$ \\
$\mathrm{~T}_{6}$ & $100.20 \mathrm{bc}$ & $17.00 \mathrm{a}$ & $27.41 \mathrm{a}$ & $180.33 \mathrm{a}$ & $41.00 \mathrm{c}$ & $873.33 \mathrm{a}$ \\
LSD & 6.48 & 1.95 & 2.44 & 11.95 & 3.51 & 17.01 \\
$\mathrm{CV}(\%)$ & 3.61 & 7.05 & 5.80 & 4.40 & 4.45 & 1.22 \\
LS & $*$ & $* *$ & $* *$ & $* *$ & $* *$ & $* *$ \\
\hline
\end{tabular}

LSD $=$ Least Significance Difference

$\mathrm{CV}=$ Coefficient of Variation

LS = Level of significance

** and $*=$ Significant at $1 \%$ and $5 \%$ level respectively

Within the table different letter (s) in same column indicate significance difference by DMRT

[Where, $\mathrm{T}_{0}=$ Control, $\mathrm{T}_{1=}$ Compost tea (preventive), $\mathrm{T}_{2}=$ Compost tea (Curative), $\mathrm{T}_{3=}$ Streptomycin (preventive), $\mathrm{T}_{4=}$ Streptomycin (Curative), $\mathrm{T}_{5=}$ Cupravit (preventive) and $\mathrm{T}_{6=}=$ Cupravit (Curative)]

\section{Plant height (cm)}

Effect of different treatments on plant height was variable that ranged from 95.97 $\mathrm{cm}$ to $107.10 \mathrm{~cm}$ (Table 1). Highest plant height $(107.10 \mathrm{~cm})$ was observed in $\mathrm{T}_{2}$ (compost tea curative) which was statistically similar to $\mathrm{T}_{0}$ (control) and the lowest plant height $(95.97 \mathrm{~cm})$ was in $\mathrm{T}_{4}$ (streptomycin curative).

\section{Number of tillers/ plant}

Significant effect of different treatments on the no of tiller/plant was observed (Table 1). Highest tiller number (17.20) was observed in $\mathrm{T}_{5}$ (cupravit preventive) 
which was statistically similar to $\mathrm{T}_{6}$ (cupravit curative), $\mathrm{T}_{2}$ (compost tea curative) and $\mathrm{T}_{1}$ (compost tea preventive) whereas the lowest tiller number (13.93) was in $\mathrm{T}_{3}$ (streptomycin preventive) which was statistically similar to $\mathrm{T}_{4}$ (streptomycin curative) and $\mathrm{T}_{0}$ (control).

\section{Panicle length $(\mathrm{cm})$}

Mean panicle lengths ranged from $22.16 \mathrm{~cm}$ to $27.41 \mathrm{~cm}$ among the treatments (Table 1). Maximum panicle length was recorded from $\mathrm{T}_{6}$ (cupravit curative), while the minimum panicle length was in $T_{3}$ (streptomycin preventive), $T_{2}$ (compost tea curative) and $\mathrm{T}_{0}$ (control).

\section{Total number of grains/panicle}

Effect of different treatment on grain number /panicle varied significantly (Table 1). Mean number of grain /panicle ranged from 132.69 to 180.33 . The highest number (180.33) of grain /panicle was recorded in $\mathrm{T}_{6}$ treatments plant and the lowest number (132.69) of Grain/ panicle was recorded in $\mathrm{T}_{0}$ control plants.

\section{Chaffy grain number/ panicle}

The number of chaffy grain number/panicle was also influenced by the different treatments (Table 1). The highest number (51.33) of chaffy grain /panicle was recorded in $\mathrm{T}_{3}$ (streptomycin preventive) and the lowest number (41.00) of chaffy grain number/panicle was recorded in $\mathrm{T}_{6}$ (cupravit curative) which was statistically similar to $\mathrm{T}_{2}$ (compost tea curative), $\mathrm{T}_{4}$ (streptomycin curative) and $\mathrm{T}_{5}$ (cupravit preventive).

\section{Grain weight (g/plot)}

The average grain weight $(\mathrm{g}) / \mathrm{plot}$ were also varied statistically (Table 1$)$. Maximum weight (873.33g) of grain was recorded in $\mathrm{T}_{6}$ (cupravit curative) and the lowest weight $(726.67 \mathrm{gm})$ of grain were also recorded in plants with $\mathrm{T}_{0}$ (control) which was statistically similar to $\mathrm{T}_{4}$ (streptomycin curative).

Foliar application of compost tea did not show any significant effect on most of the yield contributing components except grain weight/plot. Grain weight under different treatments ranged from 726 to $873 \mathrm{~g}$. In case of spraying compost tea (preventive) the per plot yield was $826.67 \mathrm{gm}$ where compost tea (curative) 793.33g. This result indicated that the compost tea enhanced the grain weight which was supported by Ngakou et al. (2012).

Among the application options preventive and curative, curative application provided better results than preventive under field condition. This finding was supported by Mary et al. (2001). They used prophylactic and curative spraying of streptocycline $(500 \mathrm{ppm})$, streptomycin + oxytetracycline $(1: 9,250$ and 500 ppm), bactrinol-100 (500 ppm) and cowdung extract (20 g/litre) on rice cultivars 
TNI and Jyothy and observed a reduction in bacterial blight (Xanthomonas oryzae pv. oryzae) incidence and an increase in straw and grain yields in all treatments except bactrinol-100. They also reported that prophylactic and curative spraying of streptomycin + oxytetracycline and cowdung extract produced the highest grain and straw yields for TNI and Jyothy, respectively. The percentage of disease index was lower for curative (40.16) than for prophylactic (42.22) spraying.

\section{Conclusion}

The compost tea was highly effective to control bacterial leaf blight (BLB) in rice which could replace the chemical fungicides without any risk to human, animal and environment. So, growers could be motivated to apply the cost effective compost tea for efficient management of BLB of rice for better yield.

\section{References}

Anonymous. 2005. Fertilizer Recommendation Guide. Bangladesh Agricultural Research Council (BARC). New Airport Road, Farmgate, Dhaka 1215.

BBS (Bangladesh Bureau of Statistics). 2012. Statistical Year Book of Bangladesh. Ministry of Planning, Government of the People's Republic of Bangladesh. Pp 33-36.

BRRI (Bangladesh Rice Research Institute). 2004. Annual Report of Plant Pathology Division. Joydebpur. Gazipur, Bangladesh.

Fakir, G.A.1982. An annotated list of seed borne diseases in Bangladesh. Agricultural Information Service, Dhaka, Bangladesh. p.15.

FAO (Food and Agricultural Organization). 2013. FAO Rice Market Monitor. 16 (1). p.2. available at http://www.fao.org/economic/est/publications/rice-publications/ricemarketmonitor-rmm/en/.

Gomez, K. A. and A. A. Gomez. 1984. Statistical Procedures for Agric. Res. $2^{\text {nd }}$ Edition, John Wiley and Sons, New York, USA. Pp. 97-111.

Kauffman, H.E., A.P.K. Reddy, S.P.Y. Hsieh and S.D. Merca. 1973. An improved technique for evaluating resistance of rice varieties to Xanthomonas oryzae. Plant Dis. Rep. 57: 537-541.

Khan, M.A.I., M.A. Monsur, M.S. Hossain, B. Nessa, M.A.H.B. Bhuiyan, T.H. Ansari and M.A.T. Mia. 2010. Evaluation of new chemicals against bacterial leaf blight disease of rice. Eco-friendly Agric. J. 3(5): 242-246.

Kumar, M., R.L. Parate and B.N. Ninawe. 2009. Effect of botanicals, bioagents and some chemicals against Xanthomonas oryzae pv. Oryzae Akola, India: Association of plant pathologist. J. plant Dis. Sci. 4(1):60-63.

Kwok, O. C. H., P.C. Faty, H.A.J. Hoitink and G.A. Kuter. 1987. Interactions between bacteria and Trichodermaharnatum in suppression of Rhizoctonia damping off in barkcompost-media. Phytopathology. 77(8): 1206-1212.

Mary, C.A., S.K. Nair and P. Saraswathy. 2001. Efficacy of prophylactic and curative spraying on the control of bacterial leaf blight of rice. Thrissur, India: Kerala Agricultural University. J. Trop. Agric. 39(1): 73-75. 
Ngakou, A., N. Koundou and H. Koehler. 2012. The relative effects of compost and nonaerated compost tea in reducing disease symptoms and improving tuberization of Solanum tuberosum in the field. Int. J. Agric. Res. Rev. 2(4): 504-512.

Padmanabhan, S.Y. and S.S. Jain. 1966. Effect of chlororination of water on control of bacterial leaf blight of rice, caused by Xanthomonas oryzae pv. Oryzae Dowsan. Curr. Sci. 35: 610-611.

Perveen, S., Ehteshamul-Haque and A. Ghaffar. 1994. Biological control of soil borne root infecting fungi in tomato and okra. Pak. J. Bot. 26: 181-186.

Rou, P.V. 2003. Suppression of tomato early blight by spraying of animal manure based compost water extracts. Suppression of tomato early blight by spraying of animal manure based compost water extracts. Annals of the Sri Lanka Dept. Agric. 5: $175-191$.

Ryan, M., D.Wilson, P. Hepperly, J.Travis, N. Halbrendy and A. Wise. 2005. Compost tea potential is still brewing. Biocycle. 46: 30-32.

Tabei, H. and H. Mukoo. 1960. Anatomical studies of rice plant leaves affected with bacterial leaf blight, in particular reference to the structure of water exudation system. Bull. Nat. Instit. Agric. Sci. 11: 37-43.

Thein, A. and S. Prathuangwong. 2010. Novel strains of Xanthomonas oryzae pv. oryzae UV mutated induce systemic resistance in rice against bacterial leaf blight disease. Kasetsart J. Nat. Sci. 44(6): 1026-1043.

Wickramaarachchi, W.A.R.T., P.N.N. Reddy, T.V. Reddy and P.V. Rao. 2003 Suppression of tomato early blight by spraying of animal manure based compost water extracts. Suppression of tomato early blight by spraying of animal manure based compost water extracts. Annals of the Sri Lanka Dept. Agric. 2003. 5: 281-290. 